\title{
PALESTINE, INTERNATIONAL LAW AND MUSLIM UNITY*
}

\author{
Mohammad Naqib Ishan $\mathrm{Jan}^{* *}$
}

\begin{abstract}
The Palestine issue is a heart breaking politico-legal issue that has remained unresolved for so long. The issue started immediately after the disintegration of the Ottoman Empire and following the occupation of Palestine by Great Britain. Britain disregarded the will of the majority of population, facilitated, directly or indirectly, Jewish settlements and supported foreign- led Zionist movement by making an unjust and illegal promise to them to create a state for Jews in Palestine which it eventually did and in doing so it further complicated the Palestine issue an issue which the League of Nations was unable to solve due to its lack of commitment and its weak organizational structure. The issue has continued till today and is termed as "the most serious and
\end{abstract}

* An earlier version of this paper was presented at the Inaugural International Workshop and Seminar on Siyar \& Islamic States Practices in International Law, 18 \& 19 November, 2009, Faculty of Law, University of Kebangsaan Malaysia, Malaysia.

** Associate Professor, Ahmad Ibrahim Kulliyyah (Faculty) of Laws, International Islamic University Malaysia, LLB (IIUM), MCL (IIUM), PH.D (IIUM), naqib@iium.edu.my. 
prolonged unresolved political and human rights issue on the agenda of the United Nations (UN) since its inception." The inability of the UN to resolve the Palestine issue is not due to the fault of international law but due to the lack of commitment of some of the powerful members of its executive organ, that is the Security Council. These powers disgracefully have shown passivity and apparent indifference about the long and cruel Israeli occupation of Palestine. As this paper explains, the indifference on the part of the UN Security Council has enabled the Zionist state of Israel to pursue with impunity its aggressive wars, its ethnic cleaning strategy, its settlements policy, its blockades of the Palestinian cities and towns and its denial of the Palestinians' inalienable right of selfdetermination. If the powerful nations of the world failed Palestine and its people, we the Muslims must not follow suit. We must stop our infighting and unite our strength and do everything that is peacefully possible to help Palestinians to find a just solution to their problem and if possible to restore Palestine to its historical status.

Keywords: Palestine, Ottoman Empire, Great Britain, Zionist movement, League of Nations, United Nations, international law, human rights, occupation, aggressive wars, settlements policy, refugees, right of selfdetermination, Muslim unity.

\section{INTRODUCTION}

Palestine originally was a constituent state of the Ottoman Empire - an Empire that ruled it with justice, fairness and provided its inhabitants, Muslims, Christians and Jews, with equal treatment. The collapse of the Ottoman Empire, which was orchestrated by Great Britain and the European Zionists, marked the beginning of the suffering of the Palestinians. Following the collapse of the Ottoman Empire, Britain occupied Palestine and, in disregard of the will of the majority of its 
population, ${ }^{1}$ facilitated, directly or indirectly, Jewish settlements on the Palestinian lands and supported foreign- led Zionist movement by making an unjust and illegal promise to them to create a state for Jews in Palestine which it eventually did and on $14^{\text {th }}$ May 1948, the Zionist leaders declared the establishment of the state of Israel on $78 \%$ of the Palestine land and the remaining of the Palestine lands came under the occupation of Israel following the 'Six Day War' of 1967. Since the establishment of the State of Israel, Palestinians resisted the illegal occupation of their lands struggling to achieve their inalienable right of self-determination but so far the issue has remained unresolved - an issue which the League of Nations was unable to solve due to its lack of commitment and its weak organizational structure. The issue has continued till today and is termed as "the most serious and prolonged unresolved political and human rights issue on the agenda of the United Nations (UN) since its inception.” The inability of the UN to resolve the Palestine issue is not due to the fault of international law but due to the lack of commitment of some of the powerful members of its executive organ, that is the Security Council. These powers disgracefully have shown passivity and apparent indifference about the long and cruel Israeli occupation of Palestine. As this paper explains, the indifference on the part of the UN Security Council has enabled the Zionist state of Israel to pursue with impunity its aggressive wars, its ethnic cleaning strategy, its settlements policy, its blockades of the Palestinian cities and towns and its denial of the Palestinians' inalienable right of self-determination. If the powerful nations of the world

$1 \quad$ In 1914 the population of Palestine was estimated to be 689,546: 634, 133 Muslim and Christian Arabs; 55,413 Jews. In 1947 the Government of Palestine submitted an estimate of the population of Palestine to the United Nations Special Committee on Palestine. It stated on page 11 of the Supplement to the Survey of Palestine that at the end of 1946 the estimated population of Palestine was as follows: Arabs (Muslims and Christians) 1, 269,000, Jews 608,000 and others 35,000. A Survey of Palestine, Prepared in December 1945 and January 1946 for the Information of the Anglo-American Committee of Inquiry (Jerusalem: Palestine Government Printer, 1946), volume 1, pp. 103-105. According to Israeli statistics published in 1983, the number of Jews in Palestine in 1948 was 716,000, of whom 253,700 were born in Palestine and 463,000 born outside Palestine. See Statistical Abstract of Israel 1983, Israel Central Bureau of Statistics, 1983, No. 34, at 71. 
failed Palestine and its people, we the Muslims must not follow suit. We must stop our infighting and unite our strength and do everything that is peacefully possible to help Palestinians to find a just solution to their problem and if possible to restore Palestine to its historical status.

\section{PALESTINE: THE HISTORICAL PERSPECTIVE}

Palestine for over four centuries (1516-1917) was under the rule of the Ottoman Empire. The Ottoman Empire ruled not only Palestine but a vast area of the world for very long period of time ${ }^{2}$ and "offered its inhabitants many benefits throughout most of its existence. For Muslims it was considered as a defence against the non-Muslim world. For nonMuslims it offered a better life and more security than Christian states up until the 18th century. For most of its inhabitants it had offered career possibilities. And it offered peace and relative harmony to all its inhabitants despite cultural and ethnic differences." ${ }^{3}$

In the era of the Ottoman Empire, Palestine, geographically and demographically, constituted the entire 'State of Israel' and the 'Occupied Territories.' 4 The population of Palestine was called Palestinians. Palestinians mainly consisted of Muslims, Christians and Jews. Muslims were the absolute majority while the Christians and Jews were the minorities. In spite of religious and racial diversities, Palestinians maintained friendly relations with each other. The rulers of the Ottoman Empire treated all Palestinians with respect, honor and dignity. ${ }^{5}$ Palestinians were not under the yoke of the Empire, as the Jews claim in

The Ottoman "Empire based around the Turkish sultan, lasting 1300-1922, 622 years, covering at its peak (1683-1699) an area including today's Hungary, Yugoslavia, Croatia, Bosnia, Albania, Macedonia, Greece, Romania, Moldova, Bulgaria, southern Ukraine, Turkey, Georgia, Armenia Iraq, Kuwait, Cyprus, Syria, Lebanon, Israel, Palestine, Jordan, eastern and western Saudi Arabia, Oman, Bahrain, eastern Yemen, Egypt, northern Libya, Tunisia, and northern Algeria."LookLex Encyclopedia, http://icias.com/e.o/ottomans.htm.

3 Ibid.

$4 \quad$ Encyclopedia Britannica ill, Micropaedia, vol. Vll, "Palestine.”

5 Haj Amin Effendi El Husseini, Representative of the Arab Higher Committee for Palestine, 12th of January, 1937, Notes of Evidence 
order to justify their own cruelty vis- $a$-vis the Arab population. As Haj Amin Effendi El Husseini, Representative of the Arab Higher Committee for Palestine has noted:

Under the Ottoman Regime the Arabs formed an important part of the structure of the Ottoman Empire. It is wrong to say that the Arabs were under the yoke of the Turks and that their uprising and the assistance which was rendered to them during the Great War were merely intended to relieve them from such yoke. The fact is that under the Ottoman Constitution they enjoyed all rights and privileges, political or otherwise, on an equal basis with the Turks, as the Ottoman Constitution provided for one form of government of all Ottoman territories and elements. The Arabs had a complete share with the Turks in all organs of the State, civil as well as military. There were Arabs who held the high office of Prime Minister and Ministers, Commanders of Divisions and Ambassadors.... There were Arab ambassadors, provincial and district governors. There was also a large number of Arab Deputies in both Houses of the Ottoman Parliament, in proportion to their numbers as prescribed under the Ottoman Constitution....There were two Parliaments, two Constitutions. One was made in the early days of the reign of Sultan Abdul Hamid, in 1876, and the other was made after the grant of the Constitution in 1908. ..but even in the Parliament under the first Constitution there were Arab representatives. In the first Parliament, you find the President of the Council of the House of Representatives was a Deputy from Jerusalem, Yusif Dia Pasha Al Khalidi. Moreover, the administration of Arab territories was entrusted to elected Administrative Councils. Those Councils were elected and existed in the provinces, districts, and sub-districts [with extensive powers].... ${ }^{6}$

Taken from the Palestine Royal Commission on Tuesday, 12th January, 1937, published by the British Government, pp. 292-293. Ibid. 
Thus, it is not true to say that Turks mistreated Arabs or other ethnic groups in Palestine. Under the Empire, Palestinians, irrespective of their religious belief, enjoyed all their civil, social, economic and political rights, privileges and freedoms. They were not discriminated on the basis of race or religion but were rather treated on an equal basis with Turks. Turks even permitted foreign Jews to come to Palestine to conduct their religious rites, though they were not allowed to settle there.

The prevailing climate of religious tolerance and freedom of movement in the era of the Ottoman Empire enabled some foreign Jews like Theodor Herzl (1860-1904), a Jew from Budapest, Hungary, and the founder of 'Zionist Movement,' to travel to Palestine. After arriving at Palestine in 1896 he utilized the opportunity by asking his Imperial Majesty, Sultan Abdül Hamid II, Emperor of the Ottomans about the possibility of establishing a state for the Jews in Palestine. But the Sultan told him that “...as long as I am alive I would rather have my flesh be cut up than cut out Palestine from the Muslim land."7 The Zionist leaders including Theodore Herzl and Chaim Weizmann (1874-1952) were, however, adamant and they began to conspire with anyone who supported them in fulfilling their racist desire to establish a state for Jews in a Muslim land. Zionism, with its xenophobic philosophy and evil intent rigorously and violently pursued its hideous goal. As a brain child of some nationalists Jews in Central and Eastern Europe, the Zionist movement was established in the wake of growing pressure on Jews in those regions to assimilate totally or risk continuing persecution. It aimed at colonizing Palestine and with that purpose in mind, it fabricated a tale that Palestine was "a land without people for a people without a land...." This was a naked lie as this land was not empty but "had a flourishing Palestinian Arab population including a small number of Jews." "Zionist leaders wanted a complete dispossession of indigenous Arabs to establish a Jewish state on Palestine for Jews alone and got help doing it from the British

7 Wikipedia, the free encyclopedia, available at: http://en.wikipedia.org/ wiki/Theodor_Herzl.

$8 \quad$ Stephen Lendman, The Ethnic Cleansing of Palestine by Ilan Pappe, A Review of Ilan Pappe, Global Research, February 7, 2007, available at: http://www.globalresearch.ca/index.php? context $=$ va\&aid $=4715$.

$9 \quad$ Ibid. 
Empire - an Empire which following the First World War and the collapse of the Ottoman Empire began to rule Palestine.

The collapse of the Ottoman Empire was orchestrated by both the British Empire and the Zionist movement. During the World War I in 1916 British Prime Minister, Lloyd George, after conspiring with some European Jews, ordered the invasion of Palestine. Dr. Chaim Weizman, a Jewish chemist, developed a powerful process for producing explosives that the British desperately needed. As payment for the use of his process, he negotiated with the British to promise to provide "a national home for my people." Weizman succeeded in raising the 'Zionist movement' into global attention and he ultimately became the first President of the new 'State of Israel' which was later established in Palestine by the help of the British Empire. Zionism from its inception was a consciously colonial project - a project that was started in the 1880s when the European Jewish settlers had begun arriving in Palestine. The rationale behind the Zionist project was to change the demography of Palestine and to pave the way for the creation of a Jewish state, as in the year 1880s Jews were a tiny minority constituting only "about 5 percent of Palestine's population." 10

\section{a. British Empire: 'The Sponsor of the Zionist Project'}

The Zionist leaders like Chaim Weizmann and Theodore Herzl were fully aware that a tiny Jewish minority in Palestine would be unable to create the intended Jewish state without the expulsion of the Arabs who constituted the absolute majority of the population of Palestine and replacing them with foreign Jews. To do these the Zionist leaders needed help from the British Empire which the latter in pursuance of its own interest eventually facilitated and helped them to produce a state for the Jews. Indeed the British Empire, as pointed out by Richard Becker, "became the sponsor of the Zionist project with the issuance of the

$10 \quad$ Richard Becker, 'The Palestinian People Must Have the Right of Return,' International Relations, Geo Strategy and Middle East Affairs Journal, LeadAShip.com, October 11-18, 2005. 
Balfour Declaration in 1917." "11 The Balfour Declaration, ${ }^{12}$ which was made in pursuance of the British interest, ${ }^{13}$ stated:

“His Majesty's Government views with favor the establishment in Palestine of a national home for the Jewish people ... it being clearly understood that nothing shall be done which may prejudice the civil and religious rights of existing non-Jewish communities in Palestine."

This unholy declaration totally ignored Arabs who constituted the absolute majority of population in Palestine. As Ismail Zayid, a Palestinian scholar has rightly pointed out that: "It is interesting to note that the four-letter word 'Arab' occurs not once in this document. ... To refer to the Arabs who constituted 92 percent of the population of Palestine and owned 89 percent of its land, as the non-Jewish communities, is not merely preposterous but deliberately fraudulent ... Palestine did not belong to Balfour to assume such acts of generosity." ${ }^{4}$ The Balfour Declaration promised a national home for Jewish people, but it only promised civil and religious rights for the "non-Jewish communities." The moment the Declaration became public, Arabs detested it while Jews celebrated it. ${ }^{15}$

11 Ibid.

12 The Balfour Declaration, 2 November 1917, was a formal statement of policy by the British Government that promised a national home for the Jewish people. Yapp, M.E., The Making of the Modern Near East 1792-1923, Longman, Harlow, England, 1987, 290.

13 The British interests in making that declaration and its long term motives behind its policy of allowing Jewish immigration into the League of Nations Mandate of Palestine was in order to protect the nearby Suez Canal which formed part of the sea lane to British India, and the use of Palestine as a terminus at the Mediterranean sea port of Haifa of an oil pipeline which led to the Iraqi city of Mosul, construction of which was completed in 1935. The Iraqis cut off the flow of oil via this pipeline to Haifa after the establishment of the state of Israel in 1948. See Yergin, Daniel. The Prize: The Epic Quest for Oil, Money, and Power. New York: Simon and Schuster, New York, 1991; see also http:// wapedia.mobi/en/Balfour_Declaration_of_1917.

14 Ismail Zayid, Palestine: Fifty years of ethnic cleansing and dispossession, in Dossier on Palestine, Halifax, Nova Scotia, 2002.

15 Richard Becker, supra n.10. 
The British Empire's first step in fulfilling its promise of establishing “a national home for Jewish people" was to bring Palestine under its Mandate ${ }^{16}$ which it did so following the First World War at San Remo Conference ${ }^{17}$ and was confirmed later by the League of Nations. The Mandate over Palestine, which was rejoiced by Jews but was condemned by Palestinians as they considered it as a victory for Zionism, ${ }^{18}$ enabled the British Government to fulfill its promise but it did so at the expense of the fundamental human rights of the majority of population of Palestine. This means the creation of the state of Israel was the result of a successful conspiracy between the Zionist movement and the British Empire. It was the British Empire that with the support of the United States facilitated the agenda of the Zionist movement. As Richard Becker has pointed out:

With British sponsorship and new sources of funding from the United States, the Zionist project took off after World War I. Jewish settlements and land acquisition rapidly grew. Though now a British colony, a de facto government was set up in the Zionist-controlled areas, and began building its own militia. Following the British

$16 \quad$ Following the World War I and the consequential result of it, i.e., the end of the Ottoman Empire, the victorious allied powers, including Great Britain, France, Italy, Japan, Greece, and Belgium, met at the San Remo Conference which was held in San Remo, Italy, in April 1920, to divide the Ottoman Empire in the Middle East among themselves. At the conference, Britain was awarded mandates over Palestine and Iraq, and France was awarded mandates over Syria and Lebanon. Later, Syria, Lebanon and Iraq obtained their independence and become sovereign States but for the Palestinians establishing a sovereign State remain a dream which yet to be realized.

17 The architect of the Declaration, Balfour, along with some of the Zionist leaders, attended the San Remo Conference persuading it to confirm the Declaration and award Britain the mandate over Palestine which it did. The Zionist leaders who attended the San Remo Conference included Chaim Weizmann, Nahum Sokolow, and Herbert Samuel. David Fromkin, A Peace to End All Peace: The Fall of the Ottoman Empire and the Creation of the Modern Middle East, 1990 (Owl books, 2001); See also Huneidi, Sahar S., A broken trust: Herbert Samuel, Zionism and the Palestinians, I.B. Tauris, London, 2001, 32. 
and European colonial-settler pattern-like that already established in the United States and South Africa - when the Zionists acquired an area, their aim was generally to make it exclusively Jewish. Zionist settlements or businesses were urged or required to hire only Jewish labor. As the settler population increased from about 10 percent in the early 1920s to nearly 30 percent by the end of the 1930s, the discussion of "transfer" intensified. "Transfer" meant moving the indigenous Palestinian Arab population out of Palestine to make way for the future Israeli state.

The Zionist leaders including David Ben-Gurion, Israel's first prime minister, and some of the members of the Zionist underground paramilitary group (known as Haqana) had drawn their plan of ethnic cleansing of Palestine during the British Mandate period. The plan included "large-scale (deadly serious) intimidation; laying siege to and bombarding villages and population centres; setting fire to homes, properties and goods; expulsion; demolition; and finally, planting mines among the rubble to prevent any of the expelled inhabitants from returning." ${ }^{19}$ These activities were part of the transfer plan which the Zionist leaders adopted and implemented with either explicit or implicit consent of the British Empire. The Zionist leaders made their plan public as it was clear from the statement of Ben-Gurion who said in June, 1938 to the Jewish Agency Executive that "I am for compulsory transfer; I do not see anything immoral in it." 20 The plan which was executed during the British Mandate period included:

Forcible expulsion of hundreds of thousands of unwanted Palestinian Arabs in urban and rural areas accompanied by an unknown number of others mass slaughtered to get it done. The goal was simple and straightforward to create an exclusive Jewish state without an Arab presence by any means including mass-murder. Once

\footnotetext{
19 Stephen Lendman, The Ethnic Cleansing of Palestine by Ilan Pappe, A Review of Ilan Pappe, Global Research, February 7, 2007, available at: http://www.globalresearch.ca/index.php?context=va\&aid=4715. Ibid.
} 
begun, the whole ugly business took six months to complete. It expelled about 800,000 people, killed many others, and destroyed 531 villages and 11 urban neighborhoods in cities like Tel-Aviv, Haifa and Jerusalem. The action was a clear case of ethnic cleansing that international law today calls a crime against humanity for which convicted Nazis at Nuremberg were hanged. ${ }^{21}$

The sad truth, however, is that "Israelis have always remained immune from international law even though names of guilty leaders and those charged with implementing their orders are known as well as the crimes they committed."22 The crimes Israelis committed "included coldblooded mass-murder; destruction of homes, villages and crops; rapes; other atrocities; and massacres of defenseless people given no quarter including women and children." ${ }^{23}$ However, through lies and deceptions Israelis suppressed and expunged the crimes from official accounts The Israeli historiography made up the tale that Palestinians left voluntarily fearing harm from invading Arab armies. ${ }^{24}$ The tale was not true but was a naked lie just to cover up Israeli crimes which "Palestinians call the Nakba - the catastrophe or disaster that's still a cold, harsh festering unresolved injustice.” ${ }^{25}$ Before the British mandate was ended, "Jewish forces completed the expulsion of about 250,000 Palestinians the Brits did nothing to stop." ${ }^{26}$ Palestinian Arabs did strongly oppose further Jewish immigration but to no avail, as the British sided with the Jews. British gave Zionist settlers preferential treatment. It led to uprisings in 1929 and 1936, the later one lasting three years before being brutally suppressed. In its wake, Britain expelled Palestinian leaders making their people vulnerable to Jewish forces. Consequently by the time World War II broke out the Zionist defense forces which used to be called 'Haqana' had been greatly strengthened enabling them to force more Arabs to vacate their lands to pave the way for Jewish settlement.

\begin{tabular}{ll}
\hline 21 & Ibid. \\
22 & Ibid. \\
23 & Ibid. \\
24 & Ibid. \\
25 & Ibid. \\
26 & Ibid.
\end{tabular}




\section{b. League of Nations: The Failure to Resolve Palestine Issue}

The period between 1922 to 1947, i.e. when Palestine was under the British Mandate, marked the intensification of ethnic cleansing in Palestine. The Zionist movement with the sport of its sponsors carried out its apartheid based project before the naked eyes of the League of Nations. The League of Nations, which was established in 1919 under the Treaty of Versailles to promote international cooperation and to ensure peace and security of the world, not only failed to achieve its goal but became a mere tool at the hands of the major powers who were victorious in the First World War. These powers even influenced the League of Nations to approve the British Mandate over Palestine which it did in July 1922 and in doing so it sanctioned the Balfour Declaration which promised 'a national home for the Jewish people' in Palestine. The League of Nations not only failed Palestine and its people but it also failed to prevent the Second World War and the massacre of Jews at the hands of Europeans. In the course of the Second World War, "Hitler and the Nazis carried out the mass murder of six million Jewish people..."27 but the League of Nations could not do anything to prevent this tragic incident. The major world powers, including the British Empire and the United States, which formed the backbone of the League of Nations and now became the sponsors of the project of Zionist movement "had paid scant attention to the persecution of Jews and other peoples in the 1930s. Riddled with anti-Semitism themselves, they saw Nazi Germany as a club against their main enemy of the time, the Soviet Union." ${ }^{28}$ The indifference to the plight of the Jews continued even after these powers entered the war against Germany. They began to show their sympathy, albeit not sincerely, after the war was over. As Richard Becker has pointed out:

After the war was over, however, the U.S. leaders hypocritically channeled world sympathy for the suffering of the Jewish people into support for the creation of the Israeli state-at the expense of the Palestinians. The Palestinians had nothing to do with

\begin{tabular}{ll}
\hline 27 & Richard Becker, supra n.10. \\
28 & Ibid.
\end{tabular}


the Nazi atrocities. The great majority of Jewish survivors of Nazi genocide who wanted to leave Europe after WW II wished to emigrate to the United States, as many as 80\% according to a New York Times poll. (Rita Freed, War in the Mideast, New York, Worldview, 1972). It would not have been difficult for the U.S. to absorb 400,000 Jewish refugees, particularly given the fact that the U.S. mainland had suffered no damage during the war and its economy was booming. U.S. corporate and government leaders opposed opening the doors to the survivors of the Nazi persecution, fearing that many were influenced by communist and socialist ideas. The Zionist leaders were well aware of the desire of the European Jewish survivors to come to the U.S. and they were equally opposed. As Chaplain Klausner, a Zionist organizer put it: "I am convinced that the people [the Jewish refugees] must be forced to go to Palestine." ${ }^{29}$

The Zionist organizers, like Chaplain Klausner, were convinced that the persecuted Jews must go to Palestine because the persecutors now turned the sponsors already promised to establish for them a national home in Palestine. This was the reason why Zionists with the help of British and the US continued almost uninterruptedly their activities of uprooting Palestinians and replacing them by Jews from all over the world since 1922 until 15 ${ }^{\text {th }}$ May 1948 when Britain departed Palestine, and is still continuing today. On $14^{\text {th }}$ May 1948, a day before British departed Palestine, the Jewish People's Council declared the establishment of the state of Israel on $78 \%$ of Palestine land, intensified its ethnic cleansing and land grabbing for the purpose of constructing settlements for the foreign Jews. The United States was the first country to recognize Israel. A year later, i.e., on 11 May 1949, Israel was admitted as a member of the UN, ${ }^{30}$ the successor of the League of Nations, even though it came into existence through violence, and the violations of the laws which the UN calls to be observed.

\footnotetext{
$29 \quad$ Ibid. See also Peoples Press Palestine Book Project, Our Roots Are Still Alive, Boston, People’s Press, 1977.

30 Admission of Israel to the United Nations, General Assembly Resolution 273 (III), 11 May 1949.
} 


\section{c. Partition of Palestine: A Question of Justice}

The UN, however, before admitting Israel as a member, discussed the question of the future of Palestine. The question was discussed at the Special Session of the UN General Assembly where two solutions were proposed: ${ }^{31}$

1. The creation of a single democratic Arab-Jewish State in which Arabs and Jews would enjoy equal rights.

2. Partition Palestine into two free, independent and democratic States - an Arab and a Jewish one.

The first solution was found to be unworkable because Arabs and Jews insisted that they were unable to live together due to the deterioration of their relations. Since the two people could not live together within the boundaries of a single State, "there is no alternative but to create, in place of one country, two States-an Arab and a Jewish one.”

The second solution was consequently adopted by the UN General Assembly in its resolution 181 of November 29, 1947..$^{32}$ Palestine was partitioned into Jewish and Arab States, with Jerusalem to be an internationalized city. ${ }^{33}$ The UN resolution 181 allocated fifty eight percent of historic Palestine to Israel, with 44 percent to go to the creation of a Palestinian state. Palestinians comprised 70 percent of the population at the time. The Jews accepted the partition of Palestine, though not sincerely, but the Palestinians and the Arab League rejected it on the ground of

$31 \quad$ See UN Debate on Palestine - Remarks of Soviet Representative Andrei Gromyko, May 14, 1947. UN GA, A/PV.125, 26 November 1947.

32 The UN GA Res. 181, 1947: In favour: 33-Australia, Belgium, Bolivia, Brazil, Byelorussian S.S.R., Canada, Costa Rica, Czechoslovakia, Denmark, Dominican Republic, Ecuador, France, Guatemala, Haiti, Iceland, Liberia, Luxemburg, Netherlands, New Zealand, Nicaragua, Norway, Panama, Paraguay, Peru, Philippines, Poland, Sweden, Ukrainian S.S.R., Union of South Africa, U.S.A., U.S.S.R., Uruguay, Venezuela. Against: 13-Afghanistan, Cuba, Egypt, Greece, India, Iran, Iraq, Lebanon, Pakistan, Saudi Arabia, Syria, Turkey, Yemen. Abstained: 10-Argentina, Chile, China, Colombia, E1 Salvador, Ethiopia, Honduras, Mexico, United Kingdom, Yugoslavia (www.yale.edu/lawweb/avalon/ un/res181.htm).

$33 \quad$ UN GA Res. 181, 1947. 
being unlawful, unjust, undemocratic (as the wish of majority was not taken into consideration) and grossly unfair, as it granted the "Jewish State" fifty eight percent total area of Palestine. Consequently, fighting between Arabs and Jews broke out but since Jews were well armed and well equipped by their sponsors they crushed Arab resistance and thereafter the Zionist paramilitaries began to terrorize and drive out the Palestinian population. As Richard Becker has pointed out:

In January 1948 the Haganah and the Irgun, Zionist paramilitary forces, began to carry out "Plan Dalet." Under this plan, they staged nighttime attacks on "quiet" Palestinian villages - those not involved in fighting. Haganah and Irgun units would typically plant explosives around houses, drench them with gasoline and open fire. The point was to terrorize and drive out the Palestinian population. Villagers left their homes, but typically went only as far as the next village, a situation unacceptable to the Israeli leaders. ${ }^{34}$

The situation was not acceptable to the Zionist terrorist groups, like Haganah and the Irgun, because the Arab population of Palestine were not entirely wiped out. So the Zionists began to massacre the Arab population in order to fully realize their policy of 'transfer.' As Richard Becker has pointed out:

The April 9, 1948, massacre of the entire village of Deir Yassin by the Irgun raised "Plan Dalet" to a new level of brutality. When it was over, more than 200 children, women and men lay dead. It was meant as a warning to all Palestinians. While the Jewish Agency "condemned" the Deir Yassin massacre in words, on the same day it brought the Irgun into the military Joint Command. Twelve days after Deir Yassin, joint Irgun-Haganah forces launched a lethal attack on the Palestinian areas of Haifa. They rolled barrel bombs filled with gasoline and dynamite down narrow alleys in the heavily populated city while 
mortar shells pounded the Arab neighborhoods from overhead. Haganah army loudspeakers and sound cars broadcast "horror recordings" of shrieks and screams of Arab women, mixed with calls of: "Flee for your lives. The Jews are using poison gas and nuclear weapons." The Irgun commander reported that many Palestinians cried "Deir Yassin, Deir Yassin," as they fled. (Peoples Press Palestine Book Project, Our Roots Are Still Alive, Boston, People's Press, 1977). Within a week, similar tactics led 77,000 of 80,000 Palestinians to flee the port city of Jaffa. Similar operations were repeated many times. By May 15, 1948, when Israel's independence was proclaimed, 300,000 Palestinians were living and dying in abominable conditions of exile in Lebanon, Gaza, Syria and the Jordan Valley. By the end of that year, the number of dispossessed Palestinians had grown to $750,000 .^{35}$

Richard Becker has noted further that "in the 1948 war, Israel, with its superior economic and military resources and its support from the Western powers, ended up conquering 78 percent of Palestine. The Israeli military strategy was not just to conquer land, but to drive out as much of the Palestinian population as possible from that land. Nearly 90 percent of the Arab population was forcibly "transferred" to make way for the new Israeli state. Their farms, work places and homes were stolen, forming an indispensable foundation for the new Israeli economy and state." 36

The Israeli state was and still is backed and fully equipped by its ally, the US. The US and other Western powers did help Israel to implement its policy of transfer not for free as they used this surrogate state as a watchdog to look after their selfish interest in the region. Some of the watch dog role which Israel played for its sponsors are mentioned by Richard Becker. He writes:

An early opportunity to show Israel's "watchdog” role came in 1956. That year, the nationalist Egyptian

$\begin{array}{ll}35 & \text { Ibid. } \\ 36 & \text { Ibid. }\end{array}$


government of Gamal Abdel Nasser nationalized the Suez Canal, the strategic waterway connecting the Mediterranean Sea to the Indian Ocean. Under Nasser, Egypt was seen as the leading force in the decolonization struggle in the Middle East. Nasser's “discourtesy" enraged Britain and France. Britain wanted to regain control of the Suez Canal. France saw Egypt as the key ally of the National Liberation Front, which was fighting to free Algeria from French rule. In October 1956, Israel launched a surprise attack on Egypt. A few days later, British and French paratroopers landed in the Suez Canal zone and elsewhere in Egypt. The aim was to overthrow the Nasser government and return the Suez to British control. As its reward, Israel would keep Gaza and the entire Sinai Peninsula. Nothing could have made Israel's role clearer than the 1956 war. But the results of the war did not stand. Worldwide outrage opposed this blatant imperialist intervention. The Soviet Union threatened to intervene on the side of Egypt. And the U.S. government opposed the attack, though for very different reasons. The United States did not want to see its imperialist rivals, Britain and France, strengthened in the Middle East. In the late 1950s and 1960s, U.S. military aid poured into Israel. With invaluable assistance from the U.S., Israel developed nuclear weapons. ${ }^{37}$

The Western powers were aware of the ethnic cleansing policy of the Zionist leaders but, because of their selfish interests, they consciously allowed the Zionist regime to carry out its policy by massacring or expelling Palestinians from their homes and their lands, and replacing them by foreign Jews. ${ }^{38}$ The expulsion of Palestinians was a premeditated

\footnotetext{
$37 \quad$ Ibid.

38 Amnesty International has documented Israel's inhumane treatment of its Palestinian subjects citing arbitrary arrests, torturing detainees, destroying or sealing the homes of Arab suspects and their relatives, confiscating land, destroying crops, and diverting precious water from thirsty Palestinians in the desert to fill the swimming pools and water the lawns of Israeli settlers. See George W. Ball and Douglas B. Ball,
} 
strategy as it was already envisaged in the ideology of Zionism - an ideology which is behind the Palestinian dispossession. In the period between 1948 and 1967 the apartheid regime of Israel ${ }^{39}$ grabbed seventy two percent of the territory of Palestine and expelled, directly or indirectly, approximately one million Palestinians, who became refugees. The remaining 28 percent of the territory of Palestine, including East Jerusalem, Gaza Strip and West Bank remained outside the control of Zionist state of Israel until $1967 .{ }^{40}$ On June $5^{\text {th }}$ of that year, Israel launched an aggressive war (known as the 'Six-Day War') against the United Arab Republic (Egypt, Syria, and Jordan). It quickly won the war through the illegitimate use of force and brought the remaining 28 percent of the Palestine territory under its occupation.

\section{ISRAEL'S VIOLATIONS OF INTERNATIONAL LAW}

Since the Six Day War of 1967 till today, Israel, with the support of its Western allies, persistently violates rules of international law with impunity. One of the important rules of international law which Israel has persistently violated is the norm that prohibits acquisition of territory by the use of force. The other most important rule of international law which Israel consistently breached is the rule concerning the Palestinian people's right to self-determination. Israel has also violated rules of international humanitarian and human rights laws. This chapter analyzes these rules, highlights Israel's arrogant attitude towards them and the failure of the international community to enforce the rules of international

The Passionate Attachment: America's Involvement with Israel, 1947 to the Present, W. W. Norton, 1992, 58.

39 “...Israeli policies in the Occupied Palestinian Territories appear so similar to the apartheid of an earlier era, a continent away...Today, perhaps we in the United Nations should consider following the lead of a new generation of civil society, who are calling for a similar nonviolent campaign of boycott, divestment and sanctions to pressure Israel to end its violations.” Miguel d'Escoto Brockman's statement at the UN General Assembly on the Question of Palestine, November 29, 2008.

$40 \quad$ Between 1948 and 1967 Gaza was administered by Egypt while West Bank was under the control of Jordan. 
law vis-à-vis Israel. If all nations are bound by these peremptory rules or norms of international law why should Israel be the exception.

\section{a. Violation of the obligation not to acquire territory by the use of force}

The prohibition of the use of force in international relation is enshrined in the UN Charter and is describe by the ICJ as jus $\operatorname{cogen}^{41}$ or peremptory norm - a norm that cannot be derogated from. But this non-derogable norm of international law has been derogated by Israel since its establishment till now. The most well known and well documented violation of this norm occurred on $5^{\text {th }}$ June 1967 when Israel waged a pre-emptive war against her Arab neighbours including Egypt, Syria, Jordan and Iraq. The 1967 war is known as the Six Day War because it took Israel, which was well-armed by its allies in the West, six days to defeat the Arabs and forcibly conquer the Sinai Peninsula ${ }^{42}$ and the Gaza Strip from Egypt, the West Bank from Jordan and the Golan Heights from Syria.

The Six Day War was an aggressive war, not a defensive one as claimed by Israel. During the course of the UN Security Council debates over the war, Israel argued that it was acting in anticipation of what it believed would be an imminent attack by Arab States. In effect Israel attempted to justify its aggressive war by invoking the so-called 'anticipatory self-defence.' The term 'anticipatory self-defence,' which is often interchangeably used with the term 'pre-emptive self-defence, generally understood to mean 'the use of force in self-defence against an imminent attack.' ${ }^{43}$ Anticipatory self-defence is said to be based on 'military necessity,' according to which 'the best defence is to attack first and break up the enemy forces before they have time to move.' Its

\footnotetext{
$41 \quad$ See Nicaragua $v$ USA, ICJ reports 1986, 3; 76 ILR 349.

42 The Sinai was returned to Egypt between 1978 and 1982, as part of an Israeli-Egyptian peace treaty.

43 See Murphy, S.D., 'The Doctrine of Pre-emptive Self-defence,' 50 Villanova L.Rev (2005), 699, at 703; Abdul Ghafur Hamid, 'The legality of anticipatory Self-defence in the $21^{\text {st }}$ Century World Order: A ReAppraisal,' NIL R. 2007, 441-490, at 445.
} 
rational, as advocated by its supporters, is that "in an era of nuclear weapons and sophisticated missile systems, it would be foolish and selfdefeating to await the attack by another State." ${ }^{44}$ Assuming that international law recognizes anticipatory self-defence, which actually it does not as explained later, Israel could not rely on it as the element of military necessity was absent when Israel attacked her Arab neighbours as the Arabs were and still are not as well equipped as Israel and that the Arabs had no nuclear weapons and they still lack such a destructive weapon nor they, unlike Israel, were and still are equipped with the sophisticated missile to wage war. The rationale behind the anticipatory self-fence, as was laid down by the advocate of this defence, was not there when Israel attacked the Arab states and as such Israel could not rely on it.

Although some writers, like Bowett and McDougal, heavily relying on the old customary international law that was developed subsequent to the Caroline incident to justify anticipatory self-defence, ${ }^{45}$ yet such a defence does not exist under either in contemporary customary international law ${ }^{46}$ or the UN Charter. ${ }^{47}$ The old customary international law in this regard did not survive the UN Charter and by adopting the Charter each member of the UN has waved its rights to those aspects of self-defence that are not specifically permitted under Article 51. The concept of self-defence under Article 51 of the UN Charter does not

\footnotetext{
$44 \quad$ Murphy, ibid.

45 See Bowett, D.W., Self-Defence in International Law, 1958, at 185-186; McDougal, ‘The Soviet-Cuban Quarantine and Self-Defence,' 57 Am. J. Int'l. L.(1963), at 597. However, the old customary international law in this regard did not survive the UN Charter and by adopting the Charter each member of the UN has waved its rights to those aspects of self-defence that are not specifically permitted under Article 51 . See Dixon, Martin, Textbook on International Law, Blackstone Press Ltd., London, $4^{\text {th }}$ ed., 2000), 301. See Dixon, Martin, Textbook on International Law, Blackstone Press Ltd., London, $4^{\text {th }}$ ed., 2000), 301.

47 Charter of the United Nations, June 26, 1945, UNTS No.993 (hereinafter: 'UN Charter'). The UN Charter in its Article 51 "restricts the right of self-defence by stipulating that the rule applies only against an armed attack.” Philip C Jessup, A Modern Law of Nations, The Macmillan Co., New York, 1952, 166.
} 
include the phrase 'anticipatory self-defense.' Article 51 makes an actual 'armed attack' as a necessary precondition for the use of force in selfdefense. Article 51 of the UN Charter reads:

Nothing in the present Charter shall impair the inherent right of individual or collective self-defence if an armed attack occurs against a Member of the United Nations, until the Security Council has taken measures necessary to maintain international peace and security. Measures taken by Members in the exercise of this right of selfdefence shall be immediately reported to the Security Council and shall not in any way affect the authority and responsibility of the Security Council under the present Charter to take at any time such action as it deems necessary in order to maintain or restore international peace and security.

The right of self-defence, as provided for in the above provision, can only be invoked if there is an actual armed attack. ${ }^{48}$ In 1967 Israel was not attacked by the Arab States. Therefore Israel had no right to attack the Arab States. This is so even if Israel's suspicion that Arabs were preparing themselves to attack Israel was well-founded. This is because the most important requirement for the exercise of self-defence is that the State invoking it must be under actual armed attack. Since Israel was not under actual armed attack she could not invoke Article 51 of the UN Charter to justify her aggressive war of 1967. Although Israel relied on the so-called anticipatory defence or 'pre-emptive attack' but this does not legitimize Israel's wrongful conduct as anticipatory defence does not fall within the ambit of Article 51 but rather it falls within the general prohibition of the use of force as enunciated in Article 2 (4) of the UN Charter. Article 2 (4) reads: "All Members shall refrain in their international relations from the threat or use of force against the territorial

$48 \quad$ "Article 51 of the Charter suggests a further limitation on the right of self-defence: it may be exercised only 'if an armed attack occurs.' This restriction in Article 51 very definitely narrows the freedom of action States had under traditional international law.” Philip C Jessup, A Modern Law of Nations, The Macmillan Co., New York, 1952, 166. 
integrity or political independence of any State, or any other manner inconsistent with the Purposes of the United Nations."

The Six Day War was started by Israel and as aggressor it had no right to invoke Article 51 . Contrary to the view of Israel, ${ }^{49}$ the prevailing view was and still is that the military attack by Israel violated Article 2 (4) of the UN Charter. Article 2 (4) is the most important norm of international law - a norm that embodies the primary value of the interState system, that is, maintenance of peace and security by prohibiting the use of force in international relation. ${ }^{50}$ Article 2 (4) reflects the determination of the UN members to abolish the scourge of war and make sure that international disputes must not again be resolved by military force. Article 2 (4) lays down a rule of international law that cannot be changed or modified ${ }^{51}$ by the conduct of few rogue States like Israel. It is a rule that deters aggression and defends the sovereign rights of all States so that the strong among them will not push the weaker ones to the wall. The rule contained in Article 2 (4) has crystallized as a rule of jus cogens as confirmed by the International Court of Justice in the case of Nicaragua $v$ United States..$^{52}$ This pre-emptory and nonderogatable principle of international law $^{53}$ was unfortunately derogated with impunity by Israel when it waged the Six Day War.

The Six Day War of 1967 was not the only aggressive armed attack Israel carried out against its neighbours in violation of clear norms

$49 \quad$ See Schwebel, Justice in International Law, Cambridge University Press, 1994; Israel's 1967 Six-Day War - The Legal Aspects of Coming into Possession of the Territories, June 5 2008, Elie E. Hertz. Henkin, Louis, International Law: Politics, Values and Functions, Kluwer Law International, 1995, 146. (1990), 146. Henkin, Louis, 'Force, Intervention and Neutrality in Contemporary International Law,' ASIL Proceedings, 1963, 148-149. Military and Paramilitary Activities (Nicar. v. U.S.), (1986) ICJ Rep. 14, 190.

53 The ICJ prescribed the prohibition of the use of force as a peremptory norm (jus cogens norm) of international law. Committee of U.S. Citizens Living in Nicaragua v. Reagan, 859 F.2d, 929, 940 (D.C. Cir., 1988). A peremptory norm is a norm that has been accepted and recognized by the international community of States as a whole and from which no derogation is permitted and which can be modified only by a subsequent norm of general customary international law having the same character. See Vienna Convention on the Law of Treaties 1155 UNTS 331, Art. 53. 
of international law, as it did carry out such attacks against Iraq in 1981 and against Lebanon on several occasions, the latest was in 2006. ${ }^{54}$ What makes the Six Day War significant is that it enabled Israel to expand illegally its borders by capturing Gaza, Golan Heights of Syria, the West Bank, all of East Jerusalem, ${ }^{55}$ ethnically cleansed hundreds of thousands of Palestinians by forcing them to become refugees, and, along with the 1973 war (involving Israel, Egypt and Syria) led to the conclusion of peace treaty between Egypt and Israel at Camp David in 1979. Most of these wars including the Six Day War were aggressive wars that were initiated by Israel with the sole desire to acquire by the use of force more territories belonging to the Arabs and as such they were condemned by the international community. On $22^{\text {nd }}$ November 1967 the UN Security Council adopted resolution 242 that "[emphasized] the inadmissibility of the acquisition of territory by war..." and called upon Israel to withdraw its occupying forces from territories it occupied as the result of its aggressive war in $1967 .{ }^{56}$ Resolution 242, which was adopted under Chapter VI of the UN Charter, reads in part:

The Security Council, expressing its continuing concern with the grave situation in the Middle East, emphasizing the inadmissibility of the acquisition of territory by war and the need to work for a just and lasting peace in which every State in the area can live in security, Emphasizing further that all Member States in their acceptance of the Charter of the United Nations have undertaken a commitment to act in accordance with Article 2 of the Charter, 1 . Affirms that the fulfillment of Charter principles requires the establishment of a just and lasting peace in the Middle East which should include the application of both the following principles: (i) Withdrawal of Israel armed forces from territories occupied in the recent conflict; (ii) Termination of all

See Mohammad Naqib Ishan Jan, 'International Law Issues Arising out of Israel's Military Attack Against Lebanon in 2006,' Asian Journal of International Law, Vol. 2, Issue 1-2, January-December 2007, 29-68.

55 Encyclopedia Britannica: Six Day War.

$56 \quad$ UN SC Res. 242, November 22, 1967. 
claims or states of belligerency and respect for and acknowledgment of the sovereignty, territorial integrity and political independence of every State in the area and their right to live in peace within secure and recognized boundaries free from threats or acts of force.... ${ }^{57}$

Israel has failed to abide by this resolution as she refuses to withdraw its forces from the territories she captured in 1967 and has continued to build illegal settlements to settle foreign Jews on those lands. Israel is well aware of the rule of international law that acquisition of territory by the threat or use of force is illegal and yet she continuously breaches this rule with impunity. Even if she was ignorant of this well established rule, which is not an excuse, she must have become aware in 2004 when the ICJ declared its Advisory Opinion in the Legal Consequences of the Construction of a Wall in the Occupied Palestinian Territory ${ }^{58}$ that the acquisition of territory by use of force was illegal.

All the territories, except Golan Heights of Syria, which Israel occupied subsequent to the Six Day War were the Palestinian territories. The occupation of these territories has been recognized as contrary to the peremptory norm of international law that prohibit the use of force and thus illegal. There have been a number of resolutions passed by the UN Security Council to this effect. ${ }^{59}$ The Council has repeatedly called for Israel to withdraw. ${ }^{60}$ The Council also prohibited any measures by Israel which purports to alter the character or status of the occupied Palestinian territories. Israel's occupation of the Palestinian territories is

\footnotetext{
$57 \quad$ Ibid.

$58 \quad$ Legal Consequences of the Construction of a Wall in the Occupied Palestinian Territory (Advisory Opinion), ICJ, 9 July 2004.

$59 \quad$ UN SC Res 3314.

UN SC Res 242, November 22, 1967. For the drafting history of SC Res. 242 which indicates that the Security Council had no intention of endorsing Israeli annexation of any part of the West Bank or Gaza Strip, see J.McHugo says "Resolution 242: A Legal Reappraisal of the Right-Wing Israeli Interpretation of the Withdrawal Phrase with Reference to the Conflict between Israel and the Palestinians," 51 ICLQ, 2002, 851-882.]; Res 338, 1973.
} 
illegal and this illegality is unfortunately allowed to continue for decades. It appears that in the eyes of Israel and its powerful allies the jus ad bellum rule of international law has no meaning and this could be the reason why they continuously and blatantly violate it.

\section{b. Violation of the obligation not to construct settlements on the occupied territories}

The construction of settlements in the territories Israel occupied subsequent to its aggressive war in 1967 is a blatant violation of international humanitarian law, especially Article 49 (6) of the Fourth Geneva Convention, which states that, "The occupying power shall not deport or transfer parts of its own civilian population into the territory it occupies.” Except Israel, which disputes the applicability of this provision upon itself, the rest of the international community including the UN refer to this provision as an authority to confirm the illegality of the settlements on the occupied lands. ${ }^{61}$ The UN Security Council has also

61 The Harvard Program on Humanitarian Policy and Conflict Research (HPCR), in a Jan. 2004 policy brief entitled "The Legal Status of Israeli Settlements Under IHL," contained the following: “The Israeli government has been engaged for more than 35 years in the relocation of Israeli nationals to the territories it occupied as a result of the 1967 war through various programs facilitating, supporting, encouraging and enabling the establishment of Israeli settlements in the OPT [Occupied Palestinian Territories]. The legality of these settlements has been challenged by the other parties to the conflict... Israel argues that the Geneva Conventions are not applicable to the OPT, but that even if they were applicable, the settlements would not violate Article 49 of the Fourth Geneva Convention. According to the Israeli interpretation, Article 49 does not prohibit the voluntary transfer of the population from the occupying state to the occupied territories. The international community at large and the Palestine Liberation Organization, on the other hand, hold that Israeli settlements in the OPT do violate IHL [International Humanitarian Law], and in particular Article 49 of the Fourth Geneva Convention, since Israel's policies of promoting and facilitating the transfer of population have been instrumental in the creation and expansion of Israeli settlements in the OPT. In addition, the Hague Regulations and the Fourth Geneva 
reaffirmed the illegality of settlements on numerous occasions. In its resolution 465 of March 1980, the Security Council determined that:

\begin{abstract}
[A]ll measures taken by Israel to change the physical character, demographic composition, institutional structure or status of the Palestinian and other Arab territories occupied since 1967, including Jerusalem, or any part thereof, have no legal validity and that Israel's policy and practices of settling parts of its population and new immigrants in those territories constitute a flagrant violation of the Fourth Geneva Convention relative to the Protection of Civilian Persons in Time of War and also constitute a serious obstruction to achieving a comprehensive, just and lasting peace in the Middle East. ${ }^{62}$
\end{abstract}

In its earlier resolution the UN Security Council determined that "the policy and practices of Israel in establishing settlements in the Palestinian and other Arab territories occupied since 1967 have no legal validity and constitute a serious obstruction to achieving a comprehensive, just and lasting peace in the Middle East." ${ }^{63}$ The Human Rights Council also confirmed in its resolution 16/3/2009 that:

The continuing Israeli settlement and related activities, in violation of international law, including the expansion of settlements, the expropriation of land, the demolition of houses, the confiscation and destruction of property, the expulsion of Palestinians and the construction of bypass roads, which change the physical character and

Convention together prohibit any transfer of the Occupying Power's population, even voluntary transfers, that would alter the demographic composition of the occupied territory..."- Harvard Program on Humanitarian Policy and Conflict Research (HPCR), USA, Jan. 2004, available at: http://israelipalestinian.procon.org/viewanswers. asp?questionID $=533$.

$62 \quad$ UN SC Res. 445, March 1, 1980.

$63 \quad$ UN SC Res. 446, March 22, 1979. 
demographic composition of the Arab Occupied Territories, including East Jerusalem, and the Syrian Golan, and constitute a violation of the Fourth Geneva Convention relative to the Protection of Civilian Persons in Time of War, of 12 August 1949, and in particular article 49 of that Convention; settlements are a major obstacle to the establishment of a just and comprehensive peace and to the creation of an independent, viable. sovereign and democratic Palestinian State... ${ }^{64}$

The Human Rights Council has urged Israel to reverse its settlement policy in the occupied territories, including East Jerusalem and the Golan Height of Syrian, and, as a first step towards their dismantlement, to stop immediately the expansion of the existing settlements, including "natural growth" and related activities. On $3^{\text {rd }}$ November 2009, the UN Secretary General, Ban Ki-Moon called upon Israel to end its "provocative actions" in East Jerusalem and freeze all settlement activities in the occupied West Bank. ${ }^{65}$ However, the pariah state of Israel repeatedly ignores all international calls and continuously confiscates the Palestinian lands and builds settlements for the foreign Jews in violation of the fundamental human rights principle that says "no one can be forcibly stripped of one's property." 66 The internationally condemned Israeli settlement policy ${ }^{67}$ has also violated the right of equality as enshrined in all the international human rights instruments including the Universal Declaration of Human Rights ${ }^{68}$ (UDHR) and the

\footnotetext{
$64 \quad$ Human Rights Council, Res. 16,3,2009.

65 "The secretary general is dismayed at continued Israeli actions in occupied East Jerusalem, including the demolition of Palestinian homes, the eviction of Palestinian families and the insertion of settlers into Palestinian neighborhoods. The eviction today of a Palestinian family in East Jerusalem is just the most recent incident," UN statement quoted by Al-Jazeera, Wednesday, November, 04, 2009, 04:01 GMT.

66 Articles 2 and 17 of the Universal Declaration of Human Rights, Arts, 2 and 17.

67 Atallah Kuttab, "Human Rights in the West Bank," Human Rights Crisis in the Arab World, Center of Arab Lawyers for Research and Legal Studies, n.d., at 163.

68 UN GA Res. 217A (III), Dec. 10, 1948 (hereinafter cited as ‘UDHR’).
} 
International Covenant on Civil and Political Rights ${ }^{69}$ (ICCPR) as the settlements are built exclusively for Jews and not for the Arab inhabitants - both Muslims and Christians alike. ${ }^{70}$ Expelling the Palestinians, demolishing their houses, confiscating and settling foreigners in their place of residence do not only violate the human rights principle of equality but also violate all the rights that are listed in the international human rights instruments as when a person is deprived of his homeland he is effectively deprived of all his basic civil, political, social, cultural and economic rights. The apartheid regime in Israel through its evil-intended settlement policy effectively continues changing the demographic character of the occupied territories and East Jerusalem as it did so in the historic Palestine in $1948 .^{71}$ It has constantly ignored its commitment under the negotiated 'peace plans,' including the so-called Road Map of 2002, and has continued, through deception and lie, the implementation of its illegal settlement with the hope of giving Jewish settlers demographic superiority, enabling them to participate, alongside the Palestinians, in negotiations regarding the future of the occupied territories and thus hampering the Palestinians right to exercise self-determination. ${ }^{72}$

\section{c. Violation of the Palestinians'right of self-determination}

Palestinians, like every other people under the colonial rule, have the right of self-determination to determine their own political, economic, social and cultural development and be independent from foreign

$69 \quad$ UNGA Res. 2200 (XXI), Dec. 19. 1966, entered into force March 23, 1976 (hereinafter cited as 'ICCPR').

70 Michael Adams, 'The Universal Declaration of Human Rights and the Israeli Occupation of the West Bank and Gaza,' in Ibrahim Abu Lughod (ed.) Palestinian Rights: Affirmation and Denial, Medina Press, USA, 1982), 75-76.

71 Richard Falk, "Some Legal Reflections on Prolonged Israeli Occupation of Gaza and the West Bank,” Journal of Refugees Studies, 2.1 (1989): 44.

72 The real intent of Israeli settlement policy is to "create irreversible facts, making unlikely the achievement of self-determination by the Palestinians... Israel does not think anymore in terms of peace for land but rather wants both the land and the peace...." 
domination. ${ }^{73}$ Self-determination is a fundamental right in international law. ${ }^{74}$ It is embodied in the UN Charter, the ICCPR and the International Covenant on Economic, Social and Cultural Rights ${ }^{75}$ (ICESCR). Common Article 1, paragraph 1 of these Covenants provides that: "All peoples have the rights of self-determination. By virtue of that right they freely determine their political status and freely pursue their economic, social and cultural development." This right is also recognized in other international and regional human rights instruments such as Part VII of the Helsinki Final Act 1975 and is endorsed as erga omnes obligation by the International Court of Justice (ICJ). ${ }^{76}$

The World Congress on Human Rights recognized the right of peoples to take any legitimate action, in accordance with the UN Charter, to realize their inalienable right of self-determination. ${ }^{77}$ The UN Charter prohibits the use of force but force can legitimately be used by the colonized people, like Palestinians, to realize self-determination. Since the dismantlement of the Ottoman Empire and the occupation of Palestine by Britain, Palestinians have been denied the right to self-determination. Britain instead of choosing the path of democracy and abiding by the will

73 Self-determination is "the right of a people or a nation to determine freely by themselves, without any outside pressure, their political and legal status as a separate entity; preferably in the form of an independent State, the form of government of their choice and the form of their economic, social and cultural system. "Prazetanic F., The Basic Collective Human Right to Self-determination of Peoples and Nations as a prerequisite for peace: Its Philosophical Background and Practical Application” in Reveue de droit International, Vol. 69, 1991, 263; See also Rosalyn Higgins, 'Post-modern Tribalism and the Right of Secession,' in C. Brolmann et al (ed.), Peoples and Minorities in International Law, Martinus Nijhoff, 1993, 32; Shaw, L.: Title to Territory in Africa ,Clarendon Press, London, 1986, 93. See Wallace, R, International Human Rights Text and Materials, Sweet \& Maxwell, London, (2nd ed. 2001), 7.

UN GA Res. 2200 (XXI), Dec. 19. 1966, entered into force March 23, 1976 (hereinafter cited as 'ICESCR').

East Timor (Portugal v Australia) (Judgment), 1995, ICJ Rep102 29; Legal Consequences of the Construction of a Wall in the Occupied Palestinian Territory (Advisory Opinion), ICJ, 9 July 2004.

UN World Conference on Human Rights, Vienna Declaration and Programme of Action) June 1993, Part 2. 
of majority granted the Jews (a minority at that time constituting only 8 percent of the entire population of Palestine) the right to establish a national homeland in Palestine and thereby denied Palestinians the right to self-determination. In pursuance to their right of self-determination, Palestinians rejected the arbitrary decision of Britain and its Zionist allies, formed resistance movements and continues until today to struggle to achieve self-determination and to establish an independent state and to freely choose its own political system. ${ }^{78}$

The first and yet the most important resistance movement is the Palestine Liberation Organization (PLO). It was formed in May1964 and is now recognized as Palestinian representative by over 100 states with which it holds diplomatic relations,${ }^{79}$ and has enjoyed observer status at the UN since $1974 .^{80}$ Following Oslo Accord in 1993, Israel also officially recognized the PLO as the representative of the Palestinian people. Palestinians had expected Oslo Accord would eventually put an end to Israeli occupation, facilitate the return of refugees, and enable them to achieve their self-determination and to establish a Sovereign State. But their expectation has been shattered as Israel continues with its illegal settlements, continues to make daily incursions into Palestinian population centres and effectively eliminates any semblance of Palestinian Authority control or sovereignty. The Oslo Accord, which was brokered

$78 \quad$ Musa Dweik, 'Settlements and the Palestinian Right to SelfDetermination,' 2 Palestine-Israel Journal of Politics, Economic and Culture, 1997: "Self-determination is a two-sided concept: one is internal and pertains to the choice of a suitable governmental system; the second is international and is embodied in the right of a people to independence and not to be subject to transference or surrender against its will. It also comprises the right of a nation to secede from the state to which it belongs, to merge or unite with another one or to establish its own independent state."

79 Madiha Rashid al Madfai, The United States and the Middle East Peace Process, 1974-1991, Cambridge University Press, London, 1993, 21. "On 28 October 1974, the seventh Arab summit conference held in Rabat designated the PLO as the sole legitimate representative of the Palestinian people and reaffirmed their right to establish an independent state...”

80 See UN GA Res. 3236, Nov. 22, 1974). See also. Geldenhuys, Deon, Isolated states: a comparative analysis. Cambridge University Press. London, 1990, 155. 
by the United States, was advantageous to Israel as it made PLO to compromise on its original goal ${ }^{81}$ of liberating historic Palestine and prohibiting the existence and activities of Zionism. ${ }^{82}$ Although in 1974 the PLO called for an independent state in the territory of Mandated Palestine, the Oslo Accord obliged PLO to recognize the right of the state of Israel to exist and in return Israel allowed the establishment of a Palestinian Interim Self-Government Authority with limited power to govern West Bank and Gaza, be a partner to further negotiate the final status of Palestine and to end peacefully the conflict.

The conflict, however, has yet to be resolved, Palestinians, as a people, yet to achieve their right of self-determination and the refugees yet to exercise their basic right to return to their homes in their homeland. ${ }^{83}$ Although a Palestinian Interim Self-Government Authority has been established and Israeli forces have withdrawn from Gaza, yet this territory, like the rest of the occupied territory, still remain under the occupation as Palestinian neither control its airspace nor its borders nor have the freedom to exit from it. Contrary to the well recognized rules of international humanitarian law (IHL) as well as international human rights law (IHRL) Israel holds it under siege preventing basic necessities of life to reach people in the territory. The brutal and inhumane siege of Gaza and the

81 Helena Cobban, The Palestinian Liberation Organisation, Cambridge University Press, London, 1984, 30.

82 Palestinian National Covenant, adopted by the Palestine National Council, July 1-17, 1968, July 1-17, 1968, available at: http:// www.iris.org.il/plochart.htm, Art. 2 \& 23.

83 The principle of the right to return, as stated in the United Nations General Assembly Resolutions [194(III) of December 1948], is one of the established rules of customary international law. Return to one's own homeland "is the objective to which international law aspires; it derives from the conception of nationality in international law, being coterminous with the notions of attachment and belonging; and is supported by the concept of fundamental human rights, now including the positive legal implications of the rights to development..” Guy Goodawn-Gill, 'Voluntary Repatriation: Legal and Policy Issues,' in Gill Losecher and Laila Monahan (eds.), Refugees and International Relations, Oxford Clarendon Press, London, 1990, 255, 270; See also Mohammad Naqib Ishan Jan, "The Right of Return: Its Application to the Palestinian Refugees,” [2005] IIUM Law Journal, Vol. 13, 2005, 27 51. 
illegal settlement of Jews in the West Bank and East Jerusalem continue unabatedly causing suffering and deprivation to Palestinians. The latest testimony was the vicious and disproportionate military attack in Gaza that occurred between December 27, 2008, to January 18, 2009 causing enormous destruction of the Palestinian life and property collectively punishing an entire civilian population and thereby committing war crimes just because of few homemade rockets the military wing of Islamic Resistance Movement (HAMAS) ${ }^{84}$ fired into Israel in pursuance of their resistance to achieve self-determination. In spite of numerous UN resolutions affirming the right of Palestinians to self-determination, ${ }^{85}$ Israel

84 "The behavior by Israel in bombarding Gaza is simply the commission of wanton aggression by a very powerful state against a territory that it illegally occupies. Time has come to take firm action if the United Nations does not want to be rightly accused of complicity by omission. The Israeli airstrikes on the Gaza Strip represent severe and massive violations of international humanitarian law as defined in the Geneva Conventions, both in regard to the obligations of an Occupying Power and in the requirements of the laws of war. Those violations include: Collective punishment - the entire 1.5 million people who live in the crowded Gaza Strip are being punished for the actions of a few militants. Targeting civilians:

- the airstrikes were aimed at civilian areas in one of the most crowded stretches of land in the world, certainly the most densely populated area of the Middle East. Disproportionate military response

- the airstrikes have not only destroyed every police and security office of Gaza's elected government, but have killed and injured hundreds of civilians; at least one strike reportedly hit groups of students attempting to find transportation home from the university. I remind all member states of the United Nations that the UN continues to be bound to an independent obligation to protect any civilian population facing massive violations of international humanitarian law - regardless of what country may be responsible for those violations. I call on all Member States, as well as officials and every relevant organ of the United Nations system, to move expeditiously not only to condemn Israel's serious violations, but to develop new approaches to providing real protection for the Palestinian people.” Miguel d'Escoto Brockman's statement at the UN General Assembly on the Question of Palestine, December 27, 2008. 1969; 236 (XXIX) of November 22, 1974. 
consistently and in violation of international law has denied this right to them, continued with its illegal settlements and has constructed a barrier wall on their lands which Palestinians rightly call it an apartheid wall and the ICJ declared it illegal because it violates Palestinians' legitimate right to self determination, constitutes a de facto annexation of the occupied lands and thereby called for its destruction. ${ }^{86}$ However, Israel arrogantly dismissed the court's call, continued with its illegal construction and in addition to that prevents millions of Palestinian refugees that she forcibly displaced, to return to their homes in their homeland.

\section{d. Violation of the obligation to allow Palestinian refugees to return home}

Since its establishment as a state Israel forced, directly or indirectly, millions of Palestinians to become refugees and suffer the harsh realities of exile. These refugees are the byproduct of Israel's wrongful policy of 'ethnic cleansing' - a policy that is designed to replace the Palestinians with Jewish migrants from all over the world - which has made the Palestinians to endure for over six decades the injustices of forcible displacement from their homes that has no precedent in the modern history. Israel, by making Palestinians refugees and by inviting the Jews from all over the world to settle in the native Arab lands, has grossly violated international law and it therefore committed an international wrongful conduct for which it is responsible. A state whose conduct forces people to become refugees commits an international wrong, which creates the obligation to rectify the wrong done. ${ }^{87}$ The Cairo Declaration of Principles of International Law on Compensation to Refugees, which was concluded by the International Law Association

\footnotetext{
$86 \quad$ Legal Consequences of the Construction of a Wall in the Occupied Palestinian Territory (Advisory Opinion), ICJ, 9 July 2004.

$87 \quad$ R. Yewdall Jennings, 'Some International Aspects of the Refugee Question,' Brit. Y.B. Int'l. L., 1933, 20: 98, at 110-113; See also Luke T. Lee, 'Right to Compensation: Refugees ad Countries of Asylum,' Am. J. Int'l. L., 1986, 80:532, at 536-546; Daniel D.N. Nsereko, 'The Right to Return Home,' Indian J. Int'l. L., 1981, 21: 335, at 338-341.
} 
in 1992, ${ }^{88}$ affirms this principle by providing in its Principle 2 that: Since refugees are forced directly or indirectly out of their homes from their homelands, they are deprived of full and effective enjoyment of all articles in the Universal Declaration of Human Rights that presuppose a person's ability to live in the place chosen as home. Accordingly, the state that turns a person into a refugee commits an internationally wrongful act, which creates the obligation to make good the wrong done. Israel, by making over 3 million Palestinians refugees, has not merely violated the rights as envisaged under the Universal Declaration of Human Rights but it also violated the rights, whatever their legal source, that depend to any extent for their full and effective enjoyment on the refugees' ability to live in their own country. ${ }^{89}$ Thus, the act of generating refugees grossly violates human rights law. It may also constitute an interference with the right of self-determination ${ }^{90}$ - a right that is well established in customary international law. ${ }^{91}$ Even, as some international law scholars argue, the act of generating refugees may amount to 'genocide' if it is “committed with the intent to destroy, in whole or in part a national ethnic, racial or

88 The 1992 Cairo Declaration of principles of International Law on Compensation to Refugees, 65 ILA , Conference Report (1992), reprinted in Am. J. Int'l. L., 1993, 85:157 (hereinafter: 'The 1992 Cairo Declaration'). Lee, supra n. 87, at 539.

Self-determination, which refers to the right of people to "freely determine, without external interference, their political status and to pursue the economic, social and cultural development," is included in numerous international instruments. this principle is laid down in Article 1 of the UN Charter and is elaborated in UNGA Res. 1514 (XY) (Dec. 1960); UNGA Res. 2105 (XX) (Dec. 1965) recognized the legitimacy of the struggle of colonial people against colonial domination in the exercise of their right to self-determination and independence and invited all states to provide material and more support to national liberation movements in colonial territories. UNGA Res. 2625 (XXV) (Oct. 1970) devoted 8 paragraphs to the right of self-determination laying down the duty of every state to realize this right and promote its realization as well as to refrain from any forcible action which deprives people of this right; in resistance to such forcible action people are entitled to seek and receive support. This right is furthermore laid down in Article 1 of the ICCPR as well as Article 1 of the ICESR.

$91 \quad$ Christa Meindersma, 'Legal Issues Surrounding Population Transfers in Conflict Situations,' XLI NILR, 1994, 31, at 61. 
religious group...," ${ }^{92}$ as the trauma experienced by refugees, when they were forced out of their countries often under inhuman circumstances, leaving everything behind, might involve physical and mental destruction. ${ }^{93}$ The tragic experience of losing one's homes, every link to the country where one was born and where one's parents were buried certainly might have caused serious bodily and mental harm to the displaced people. The act of uprooting a national ethnic or religious group from the land to which they have special ties with is an "effective physical destruction"94 of that group and it therefore constitutes an international crime ${ }^{95}$ for which the perpetrators of it may be individually responsible, but it also raises the civil liability of Israel as a refugee generating state. The failure of the state of Israel to observe her obligations under international law surely entails her civil liability. A state, including Israel, which forcibly, either directly or indirectly, transforms a racial, religious, social or political group into refugees cannot be said to have fulfilled her international obligations to protect persons within her territory on the basis of human rights. Israel has also violated relevant principles of international humanitarian law ${ }^{96}$ by resorting to deportation and in so doing she has

92 See Convention on the Prevention and Punishment of the Crime of Genocide, 78 UNTS 277, Art II. According to Luke T. Lee, supra. 87, at 539. “... the act of generating refugees might qualify as an 'international crime’ which would put it at par with slavery, genocide and apartheid.” Y. Dinstein, 'Collective Human Rights of Peoples and Minorities,' Int'l. Comp. L.Q., 1976, 25:102, at 105. Christa Meindersma, 'Legal Issues Surrounding Population Transfers in Conflict Situations,' XLI NILR, 1994, 31, at 62.

95 See Alfred de Zayae, 'International Law and Mass Population Transfers,' Har. Int'l. L.J., 1975, 16: 200. In the Trial of the Major War Criminals before the International Military Tribunal at Nuremberg, deportation of the civilian population in occupied territories for slave labour and for other purposes was found to be in violation of Article 46 of the Regulation Annexed to the Hague Convention IV of 1907. According to Nuremberg judgment deportation of civilians constitutes a war crime and a crime against humanity. This judgment is clearly applicable against the Zionist authorities in Israel for they have unlawfully occupied Palestine and have deported the majority of its civilian population. 
clearly committed an internationally wrongful act. ${ }^{97}$ Israel has usurped the Palestinian motherland and made the greatest number of its inhabitant refugees for decades. Since refugees have already been created, the State of Israel is responsible to provide them with the opportunity for voluntary return and compensation. ${ }^{98}$ This position has been underscored by several pertinent United Nations Security Council Resolutions, ${ }^{99}$ international agreements, ${ }^{100}$ international conferences ${ }^{101}$ as well as

subsequent two Protocols of 1977. These Conventions and Protocols are: (1) Geneva Convention for the Amelioration of the Condition of the Wounded and Sick in Armed Forces in the Field (75 U.N.T.S. 31); (2) Geneva Convention for the Amelioration of the Condition of the Wounded, Sick and Shipwrecked Members of the Armed Forces at Sea (75 U.N.T.S. 85.); (3) Geneva Convention Relative to the Treatment of Prisoners of War (75 U.N.T.S. 135); (4) Geneva Convention relative to the Protection of Civilian Persons in Time of War (75 U.N.T.S. 287). Under both customary international law as codified in such instruments as the 1907 Hague Convention Respecting the Laws and Customs of War on Land and the Nuremberg Principles (see Agreement on the Prosecution and Punishment of the Major War Criminal of the European Axis, Charter of the International Military Tribunal, Aug. 8, 1945, 82 U.N.T.S. 280 (hereinafter Nuremberg Charter), and treaty law as represented by the 1949 Geneva Convention Relative to the Protection of Civilian Persons, the influx of refugees resulting from act of deportation (i.e. deportation of civilian from occupied territories) is illegal. See Article 46 of the Regulations Annexed to the Hague Convention IV of 1907; Article 49 of the Fourth Geneva Convention, supra note 19, which states that "individual of mass forcible transfers, as well as deportations of protected persons from occupied territory ... of any other country, occupied or not, are prohibited, regardless of their motive." Lee, supra n. 87, at 538.

99 See, for instance, U.N.S.C. Res. 836 (1993), reprinted in 5(1) IJRL (1994) at 142-145; U.N.S.C. Res. 855 (1993), reprinted in Ibid., at 145-146; U.N.S.C. Res. 859 (1993), reprinted in Ibid., at 147-149.

100 The 1995 Dayton/Paris Peace Agreement on Bosnia for example, devotes an extensive Annex (no. 7) to an Agreement on Refugees and displaced Persons in which the rights of all refugees and displaced persons freely to return to their homes of origin, to have restored to them any property of which they were deprived in the first cause of hostilities since 1991, and to be compensated for any property that 
Resolutions of the UN General Assembly. Resolution 194(III) of December 1948, for example, stated in its paragraph II that the General Assembly:

\begin{abstract}
Resolved that the [Palestinian] refugees wishing to return to their homes and live in peace with their neighbours should be permitted to do so at the earliest practicable date, and that compensation should be paid for the property of those choosing not to return and for the loss of and damage to the property, which, under principles of international law or in equity should be made good by the government or authorities responsible.
\end{abstract}

This paragraph has been repeatedly affirmed by the General Assembly in its subsequent Resolutions. ${ }^{102}$ Further, in creating United Nations Governmental Experts on International Co-operation to Avert New Flows of Refugees, the General Assembly, in its Resolution 36/148 of December 16, 1981 emphasized the responsibility of the states that are responsible for the creation of refugees to provide refugees with opportunity for voluntary return and compensation. ${ }^{103}$ Later, in 1986, the

cannot be restored, were expressly established. See Paul C. Szasz, 'The Protection of Human Rights Through Dayton/Paris Peace Agreement on Bosnia,' Am. J. Int'l. L., 1996, 90: 31 at 312.

For example, the principles adopted by the London International Conference on the former Yugoslavia expressly recognized the rights of refugees to return to their homes in their own country and to compensation. See Szasz, ibid., at 312.

102 See resolutions 1604(XV) (April 21, 1961), 2452B(XXIII) (December 19, 1968), 2535B(XXIV) (December 10, 1969), 2672A(XXV) (December 8, 1970), 2792A (XXVI) (December 6, 1971), 2963A (XXVII) (December 13, 1972), 3089C (XXVIII) (December 7, 1973), 38/83A (December 15, 1983), 39/33A and H (December 14, 1984), 48/158D (December 20,1993).

103 U.N. G.A. Res. 36/148 (December 16, 1981). Notwithstanding the fact that the General Assembly in this resolution requested the Group to give due regard to the refugees' rights to return and to compensations in formulating its recommendations, there was strong opposition to their inclusion by refugee generating countries. It was argued that, since these rights addressed the post, rather than pre-flow 
General Assembly unanimously endorsed a report on the UN Governmental Experts on International Co-operation to Avert New Flows of Refugees, which calls upon member states to respect as their obligations, inter alia, "the rights of refugees to be facilitated in returning voluntarily and safely to their homes in their homelands and receive adequate compensation there-from..." ${ }^{104}$ Nsereko ${ }^{105}$ and Beyani ${ }^{106}$ noted in 1981 and 1995 respectively, that a state which forces her citizens to become refugees is guilty of an international wrong, and that the responsible state must be addressed with formidable weapon that her illegal conduct invites certain legal consequences. They argue that the responsible state must be compelled to provide refugees with the opportunity to return home and pay them compensation for the losses or injuries that they have suffered as the result of being forced to become refugees.

phenomenon, and since the Group's mandate was to avert now, rather than past, flows of refugees, these rights would lie outside the Group's purview. The counter argument was made, however, that a clear enumeration and recognition of the obligation of states to comply with these rights would discourage a potential refugee generating country from expelling its own citizens, for whatever temporary gains might result from such expulsion would be nullified subsequently by their voluntary repatriation and appropriate compensation. Accordingly, why not improve the political, social and economic condition of all groups of the population at home in the first place, instead of forcing some of them directly or indirectly to leave their country? In this sense, the rights of return and compensation would surely serve the purpose of wavering new massive flows of refugees. The logic of this counterargument being impeccable, the group agreed to adopt the refugees' rights to voluntary return and adequate compensation in its recommendations; Luke T. Lee, “Towards a World Without Refugees: The United Nations Group of Governmental Experts on International Cooperation to Avert New Flows of Refugees," Brit. Y.B. Int'l. L., 1986, 57: 317, at 329.

104 U.N. G.A. Res. 41/70 (December 3, 1986).

105 Nsereko, supra n. 87.

106 Chaloka Beyani, 'State Responsibility for the Prevention and Resolution of Forced Population Displacement in International Law,' Int'l. J. Refugee L., 1995, 130. 
Thus, Israel, by making the Palestinians refugees and by inviting the Jews from all over the world to settle in the native Arab lands, is responsible for an internationally wrongful conduct and for which she is answerable under international law. The international community, including the United Nations, must enforce the law in this regard by taking certain measures that are aimed at not only stopping Israel from further carrying out her internationally wrongful conducts but also compelling her to rectify the wrong that she has already committed. The best way to rectify the wrong she has committed, as explained in this paper, is to restore the status quo which the Palestinians were in before the wrong was perpetrated. Resitution is possibile only if the right to return of the refugees is implemented and the state of Israel is under an international obligation to allow the voluntary return of the refugees. The right of voluntary return to one's own home in one's homeland is based in law. In the case of Palestinian refugees, this right not only has its basis in law, but also in justice, in equity, in history and in their ancestral tie with their homeland. Thus, the international community in general and Israel in particular have a duty to ensure the safe and voluntary return of the Palestinian refugees to their former homes and for those who wish not to return, approriate and adequate compensation must be paid to them.

\section{ISRAEL VIOLATES INTERNATIONAL LAW WITH IMPUNITY: ICJ ADVISORY OPINION}

In the Legal Consequences of the Construction of a Wall in the Occupied Palestinian Territory ${ }^{107}$ the ICJ determined in its Advisory Opinion, which represents an authoritative interpretation of international law, that the construction of the wall being built by Israel in the Occupied Palestinian Territory, including in and around East Jerusalem, and its associated administrative régime, violates Palestinians' legitimate right to self determination, violates international law, constitutes a de facto annexation of the occupied lands and is therefore illegal. By constructing this wall, Israel, as ICJ confirmed, violated IHRL and IHL. The Court,

$107 \quad$ Legal Consequences of the Construction of a Wall in the Occupied Palestinian Territory (Advisory Opinion), ICJ, 9 July 2004. 
which is the principal judicial organ of the $\mathrm{UN},{ }^{108}$ called for the immediate destruction of the wall and payment of reparation to the affected Palestinians. The Court further called for those responsible for supervising the planning and construction of the wall on trial. The Court concluded that construction of the wall on the Palestinian lands infringes a list of well recognized international human rights including the right to selfdetermination, the right to freedom of movement, to work, to health, to education and to an adequate standard of living. In addition the court stated that the construction of the wall severely damages the fabric of the Palestinian people forcing them to leave their homes. It also, as the Court pointed out, alters the demographic composition of the Occupied Palestinian Territory and thereby contravenes both the Fourth Hague Convention ${ }^{109}$ and the Fourth Geneva Convention of $1949^{110}$ and the relevant Security Council and General Assembly resolutions. ${ }^{111}$

The ICJ tasked the UN Security Council with the responsibility for taking effective steps to ensure that Israel's illegal activities are halted and that the right of the Palestinian to self-determination is implemented. The Security Council has the authority under the UN Charter to impose, inter alia sanctions, on Israel until such time that the Court's ruling have been implemented and Palestinians enjoyed their right of selfdetermination. Five long years has passed since the ICJ's Advisory Opinion, Israel continued construction of the Wall in the occupied Palestinian territories, continued violations of international law, and yet the Security Council failed to fulfill its responsibility by taking any effective measures against Israel, even though 150 States in the UN General Assembly voted their support for the implementation of the ICJ's Advisory Opinion. Israel, with the support of its ally, the US, a veto wielding member of the UN Security Council has prevented the Council to take enforcement

\footnotetext{
$108 \quad$ UN Charter, supra n. 19, Art. 92.

109 Convention Respecting the Laws and Customs of War on Land, opened for signature 18 October 190736 Stat 2277 (entered into force 26 January 1910).

110 Geneva Convention relative to the Protection of Civilian Persons in Time of War, opened for signature 12 August 194975 UNTS 287 (entered into force 21 October 1950).

111 In particular the Court cited the General Assembly resolution 2625 (XXV) of 1970.
} 
actions against Israel to implement Palestinian rights as determined by the ICJ. This is not the fault of international law but the fault of some powerful members of the UN who lack political will and neutrality to cooperate with the Security Council to resolve the outstanding issue of Palestine.

\section{WHERE THE FAULT LIES? WITH INTERNATIONAL LAW OR POWERFUL MEMBERS OF THE UN}

The position of international law on the issue of Palestine, as discussed earlier, is clear. Under international law Palestinians have the right to self-determination and that the denial of this right by Israel is a breach of an erga omnes obligation. The Palestinian refugees have the right to return to their homes in their homeland and Israel's refusal to allow the refugees to return home is clearly a violation of all norms of IHRL as well as refugee law. ${ }^{112}$ Grabbing or annexing the Palestinian lands by the use of force and building settlements for Jews who were not even borne on those lands are vividly prohibited under international law and these activities violate both IHRL and IHL. The action of Israel vis-à-vis Palestinians is in violation of international law and therefore a wrong entailing its responsibility. ${ }^{113}$ To discharge its responsibility, Israel has to set the wrong right, i.e., to allow the Palestinian refugees to return home, to dismantle all the settlements it built on the Palestinian lands, return those lands to the rightful owners, if the land owners suffered loss

\footnotetext{
112 See Mohammad Naqib Ishan Jan, 'The Right of Return: Its Application to the Palestinian Refugees,' (2005) 13 IIUMLJ, 27-51.

113 Every internationally wrongful conduct of a State entails the responsibility of that State. This has been confirmed by the World Court in a number of cases. See Phosphates in Morocco, Preliminary Objections, (1938) PCIJ, Series A/B, No. 74, p. 10, at p. 28; Corfu Channel Case (U.K. vs. Alb.), (1949) ICJ Rep. 4, 23; Military and Paramilitary Activities in and against Nicaragua, (Nicar. vs. U.S.), (1986) ICJ Rep. 4 at paras. 283, 149 and 292; Gabèikovo-Nagymaros Project (Hungary/ Slovakia), (1997) ICJ. Rep. 7, at para. 47; Reparation for Injuries Suffered in the Service of the United Nations, (1949) ICJ Rep. 174, at p. 184; Rainbow Warrior (New Zealand/France), UNRIAA, vol. XX, p. 217 (1990).
} 
as the result of the illegal acquisition they have to be paid compensation and to implement the Palestinians' right of self-determination. The Zionist state of Israel is refusing to carry out its responsibility under international law and is doing so with impunity as some powerful members of the UN Security Council are protecting it. In the UN organizational structure the Security Council is the most powerful pillar entrusted with the responsibility to take coercive enforcement measures against a wrongdoing sate, like Israel, to enforce international law ${ }^{114}$ but it has failed to do so. The Council, which consists of fifteen members, ${ }^{115}$ five permanent with veto right and the other ten non-permanent without veto right, through its inaction, has allowed Israel to violate international law. There is lack of commitment and the sense of responsibility on the part of some of the powerful members of the UN Security Council. These powers have prevented the Council to take any meaningful enforcement measures against Israel to compel it to redress the injustices it inflicted upon the Palestinians, to allow the return of the Palestinian refugees to their homes in their homeland, to give effect to their right of self determination and to end the pain and suffering which they endured for over six decades.

The former president of the UN General Assembly, Mr. Miguel d'Escoto Brockman, recently acknowledged the lack of commitment on the part of the UN Security Council in resolving the problems faced by the Palestinians calling it a scandal and a disgraceful act that caused him and others nothing but sorrow. ${ }^{116}$ It is disgraceful the way influential members of the UN Security Council, particularly the US, a veto wielding member, have shown "passivity and apparent indifference" about the long and cruel Israeli occupation of Palestine. ${ }^{117}$ The indifference on the part of the UN Security Council enabled Zionist State of Israel to pursue with impunity its aggressive wars, its ethnic cleaning strategy, its settlements policy, its blockades of the Palestinian cities and towns and its denial of the Palestinians' inalienable right of self-determination. The

\footnotetext{
114 See UN Charter, supra n.47, Arts, 24, 25, 39, 41 \& 42.

115 Ibid., Art. 23.

116 Stuart Littlewood is author of the book Radio Free Palestine, which tells the plight of the Palestinians under occupation. He contributed this article to PalestineChronicle.com. Visit: www.radiofreepalestine. co.uk.

$117 \quad$ Ibid.
} 
Security Council's inaction has encouraged the Zionist State of Israel to tell the General Assembly, whenever it want to act against it, 'to mind your business." ${ }^{118}$ The inaction on the part of the Security Council and the indifference of some of its veto wielding members in the face of Israeli atrocities against Palestinians have provoked some political leaders in the third world countries to criticize not only the Zionist state of Israel but also the Council and some of its powerful members. ${ }^{119}$

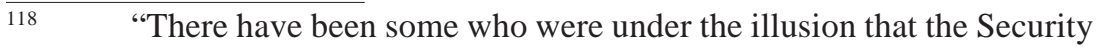
Council would do something that could help the situation. I never thought so. Now we're faced with not only with a lack of compliance but with a prime minister of Israel who has practically responded to the Security Council by saying 'mind your own business.' "It's unbelievable that a country that owes its existence to a general assembly resolution could be so disdainful of the resolution that emantes from the UN.” See Miguel d'Escoto Brockmann, 14 January 2009, http:// mwcnews.net/content/view/27863\&Itemid=1.

For instance Mahmoud Ahmadinejad, the President of Iran, in his speech at the UN General Assembly on September 23, 2008 said: "In Palestine, 60 years of carnage and invasion is still ongoing at the hands of some criminal and occupying Zionists. They have forged a regime through collecting people from various parts of the world and bringing them to other people's land by displacing, detaining, and killing the true owners of that land. With advance notice, they invade, assassinate, and maintain food and medicine blockades, while some hegemonic and bullying powers support them. The Security Council cannot do anything and sometimes, under pressure from a few bullying powers, even paves the way for supporting these Zionist murderers. It is natural that some UN resolutions that have addressed the plight of the Palestinian people have been relegated to the archives unnoticed....The dignity, integrity and rights of the American and European people are being played with by a small but deceitful number of people called Zionists. Although they are a miniscule minority, they have been dominating an important portion of the financial and monetary centers as well as the political decision-making centers of some European countries and the US in a deceitful, complex and furtive manner. It is deeply disastrous to witness that some presidential or premiere nominees in some big countries have to visit these people, take part in their gatherings, swear their allegiance and commitment to their interests in order to attain financial or media support. This means that the great people of America and various nations of Europe need to 


\section{WORLD'S MAJOR POWERS LACK POLITICAL WILL AND NEUTRALITY TO RESOLVE THE DISPUTE}

The major powers of the world, particularly the US and Great Britain, lack political will and neutrality to bring the Israeli-Palestine dispute to a just and peaceful end. Although the US and Britain are portraying themselves as peace makers and have assumed upon themselves the role of mediators, yet they are the ones who facilitated the establishment of the Zionist state of Israel in Palestine, helped it to sustain itself for over six decades and backed its uncompromising position in the negotiation of a peaceful solution which they themselves proposed. They have proposed a two state solution, one Palestine and the other Israel living side by side in peace, which the Palestinians generally agreed to the idea and seek to establish the West Bank and Gaza as the territory of a Palestinian state, with East Jerusalem as its capital, based on borders set before Israel captured land from Jordan and Egypt in its 1967 six-day war.

This solution has yet to be materialized as the states that are mediating it lack the political will and neutrality to make Israel to agree with the Palestinians aspiration. Israel dictates and not negotiates, but even if it is willing to negotiate it is not doing it in good faith and the socalled mediators are fully aware of it. Lack of good faith on the part of Israel is evident from its conducts and its uncompromising position on the future of Jerusalem and the implementation of the right of refugees to return home. It endlessly constructs settlements in the Occupied Territories including the East Jerusalem and at the same time talks about

obey the demands and wishes of a small number of acquisitive and invasive people. These nations are spending their dignity and resources on the crimes and occupations and the threats of the Zionist network against their will...Today, the Zionist regime is on a definite slope to collapse and there is no way for it to get out of the cesspool created by itself and its supporters. The Islamic Republic of Iran, while fully respecting the resistance of the oppressed people of Palestine and expressing its all-out support for it, submits its humane solution based on a free referendum in Palestine for determining and establishing the type of state in the entire Palestinian lands to the distinguished Secretary General of the UN." 
establishing a separate Palestinian state that lives in peace alongside the State of Israel. The Israeli's concept of a separate Palestinian state, as pointed by Saeb Erekat, the Palestinian chief negotiator, would be a state with limited powers of sovereignty which is not acceptable to Palestinians. On $5^{\text {th }}$ November 2009 Erekat informed the world through Al-Jazeera and other national and international media about the uncompromising position of Israel. He said, Netanyahu, the Prime Minister of Israel, had told the Palestinian president "that Jerusalem will be the eternal and united capital of Israel, that refugees won't be discussed, that our state will be demilitarized, that we have to recognize the Jewish state, that it's not going to be the 1967 borders, that the skies will be under his control." According to Erekat, "[t]his is dictation and not negotiation.” After realizing male fide intention of Israel as demonstrated in its actions and words, Palestinians have halted the negotiation saying there is no point to negotiate, under the auspices of bias mediators, with a party that dictates rather than negotiates.

The negotiation between Israel and Palestinians on the basis of a two state solution is mediated by states that have the necessary influence and power to tell Israel to act rationally, justly and to halt and dismantle the illegal settlements before the negotiation can start. These states lack political will and are biased. That is why they have failed to end the conflict. They failed in their mediation but succeeded in buying more time for Israel to continue with its illegal settlement on the occupied territories changing further the demographic situation of the territories so that Palestinians cannot even get a small portion of the historic Palestine which they aspire to get. Instead of solving the problem and freeing Palestinians from the yoke of this rogue state, the mediators provided Israel with military aids, making it the fourth largest military in the world, and remained indifferent to Israel's flagrant violation of international law and the disregard it shown to the world's opinion and the opinion of the ICJ. The Palestinian Authority President realizing this on $6^{\text {th }}$ November 2009 made it clear that the United State was favouring Israel and as such negotiation with Israel under the auspices of the United States could not proceed as it would bear no fruit for the Palestinians.

The bias on the part of the mediators is one of the reason for the prolongation of the Israel- Palestine dispute and a just solution for it is yet to be found. A biased mediator can never be an honest peace maker. That is why both UK and the US have failed to solve the dispute - failed 
because they are not neutral. Since the Balfour Declaration of 1917, ${ }^{120}$ Britain has been on the side of Israel, yet its former Prime Minister, Mr. Tony Blair, is tasked to mediate the dispute between Israel and Palestine. But so far he has failed to solve the dispute. Neither Britain nor the US has sincerely exerted its political will to end peacefully any conflict which they think, either themselves or their ally, Israel, can end it by the use of force. Britain and the US were the only nations that did not support an early ceasefire to the 2006 Israel's aggressive war against Lebanon enabling Israel to inflict more harm on its enemy. On $15^{\text {th }}$ May 2008, while celebrating Israel's sixtieth birthday, Mr. Bush said, it was the British Military officer who while leaving Palestine, gave the key to Jerusalem to a Jewish priest telling him that the city belong to the Jews.

The United States Government has been complacent to the atrocities Israel has committed for the last six decades. It has openly sided with Israel, supported its expansionist policies and either watched indifferently or covertly approved the implementation of its evil agenda of ethnic cleansing. On $15^{\text {th }}$ May 2008, during Israel's $60^{\text {th }}$ anniversary of existence, Bush, the former President of US, as I followed his speech broadcast on world's major TV channels, once again ignored the plight of Palestinian and reiterated America's support to Israel. How can the US Government, whose former president considers the Palestinian freedom fighters as terrorists and honor Israel by calling it a 'peacemaker,' be neutral? Unless changes its biased policies, the US Government cannot be a neutral peace broker in any dispute in the Middle East. Unless President Obama changes this policy, US Government cannot be a problem solver but will remain a problem maker in the Middle East. The 2003 invasion of Iraq, which was carried out at the behest of Israel and for the benefit of Israel, is good testimony to this contention. Worst of all, right now, Israel, the US ally in the Middle East, is conspiring to create a dangerous rift between Shiah and Sunni sects in the Muslim World. The conspiracy is to make Muslims fight Muslims, weaken the

The Declaration, approved by the British Cabinet, reads: "His Majesty's Government views with favour the establishment in Palestine of a national home for the Jewish people, and will use their best endeavours to facilitate the achievement of this object, it being clearly understood that nothing shall be done which may prejudice the civil and religious rights of existing non-Jewish communities in Palestine, or the rights and political status enjoyed by Jews in any other country." 
Muslim Ummah and ensure the supremacy of Israel in the region. Israel, with full knowledge of the US, deceitfully and with malevolence portrays Iran as the enemy of the Arabs while Israel as a friend. On $15^{\text {th }}$ May 2008, Mr. Bush made it clear that in any conflict with Iran "America stands with Israel.” This also shows that the US is not a peace broker in the Middle East but is rather the problem maker. Hopefully the current US President, Mr. Barak Obama, would change this mentality in the US Administration and work sincerely, honestly and with full commitment to find a just solution to the problem faced by Palestinians. Although he has been awarded the Noble Peace Prize because of his promise to bring peace to the Middle East, he has yet to fulfill his promise and Palestinians yet to be freed from the yoke of Israeli occupation.

\section{WILL MUSLIM UNITY FACILITATE THE PALESTINIANS' FREEDOM FROM THE YOKE OF ZIONISM AND ITS RACIST IDEOLOGY?}

Palestinians are frustrated with the way the powerful states of the world conduct themselves as these powers, on so many occasions, blocked the UN and its specialized agencies to recognize Palestine as a state. ${ }^{121}$ Palestinians lost hope in these powers as these powers are more

121 In the past Palestinian authorities had sought a status that required Palestine to be a state. For instance, 'in 1989, PLO applied for membership in the World Health Organization (WHO). This effort floundered, however, after the United States informed the WHO that if Palestine were admitted as a member state, the United States would withhold funding. At the time, the United States contributed one fourth of the WHO budget. PLO Chairperson Yassir Arafat called the U.S. statement "blackmail." "The WHO director general asked the PLO to withdraw the application. The WHO then voted to postpone action on the application. Thus, the WHO came to no conclusion on the issue of Palestine statehood.' 'A few weeks later, in June 1989, the PLO submitted to the Government of Switzerland ratification documents for the Geneva Conventions of 1949.' 'The validity of this ratification depended on Palestine being a state, since ratification of these four treaties is open only to "powers." 'But, like the WHO, Switzerland took no position on Palestine statehood.' See John Quigley, 'The 
interested in their own vested interests rather than helping others to attain freedom. These states preach all other states the observance of human rights, democracy and the rule of law but when it come sto Israel's massive violation of human rights and its disrespect to the rule of international law they keep both their eyes closed as if nothing has had happened. ${ }^{122}$ They have abandoned Palestinians, have shown not even sympathy to their cause, and have let them suffer the pain of deprivation, indignity and hopelessness. What is expected of us, the Muslims, is to unite our strength, which we have yet to do, to help our brothers to find a solution to their problems and to obtain their freedom. We would, if united, be at least financially and politically a source of hope for our brothers. When we are accused of breaching rules of international law the powerful nations are quick to impose on us sanctions but why we don't take a tit for tat action which is permitted under international law. Without the oil of the Muslim world their war machines could not function, their economy would stagnate. We should use our God given natural

Palestine Declaration to the International Criminal Court: The Statehood Issue,' Rutgers Law Record, The Internet Journal of Rutgers School of Law, Newark, vol. 35, 2009, available at: www.lawrecord.com. In 1989, a resolution was drafted in the UN General Assembly to construe "Palestine" as a "state" in UN documents. The United States threatened to withhold its UN dues, and the draft was not put to a vote. See PLO Delays Bid for Higher U.N. Status, L.A. Times, Dec. 5, 1989, at A5; Paul Lewis, Arabs at U.N. Relax Stand on P.L.O., N.Y. Times, Dec. 6, 1989, at A3.

122 “...the whole world knows that, among many other truths, some of our most powerful and influential Member States definitely do not believe in the rule of law in international relations and are of the view, moreover, that complying with the legal norms to which we formally commit, when signing the Charter, is something that applies only to weak countries. With such a low level of commitment, it should not be surprising that the United Nations has been unable to achieve the main objectives for which it was created. Certain Member States think that they can act according to the law of the jungle, and defend the right of the strongest to do whatever they feel like with total and absolute impunity, and remain accountable to no one.” Miguel d'Escoto Brockman, former UN General Assembly President, Quoted in PalestineChronicle.com., available at www.radiofreepalestine. co.uk. 
resources and impose oil sanction against Israel and its allies until they implement the Palestinians legal rights. We are one third of the world population and if we boycott their goods and services we would be able to pressure them economically to rethink about their position vis-à-vis Palestine and its people. We are between 1.5 -1.7 billion Muslims and if each of us contributes just one dollar per year for the Palestinians, we would be able to collect between 1.5- 1.7 billion dollars, a figure which will be more than current help of Europe and US to Israel.

We must unite our strength and take all peaceful measures to help Palestinians to find a just solution to their problem and achieve self determination. Whichever solution they choose - one state or two state solution - we must assist them to gain their independence. .We must exert all our strength to pressure the Zionist state of Israel and its allies to enforce the legal right of the Palestinian refugees to return home and for those who choose not to return to pay them adequate compensation. Once the refugees right to return is implemented the demographic situation would change in Israel and Palestinians would become the majority, as they were historically, and if democracy in its true sense of the word is practiced, which is unexpected from the racist state of Israel, and if the rule of law is abided by, which again is difficult to expect from Israel, then the Palestinians would be able to form a government and restore Palestine to its historical status and gain independence through one state solution. We must help them to achieve this. But if the Palestinians choose the two state solution it must be in accordance with the Palestinian terms and the Palestinian state that would be formed it must be a true sovereign state as defined by international law. Even in the case of the two state solution the prerequisite must be the implementation of the Palestinian refugees' right to return home - a right which is fundamental in international law.

\section{CONCLUSION}

The Palestine issue has to be resolved within the framework of international law - a law that demands the dismantlement of the illegal settlements on the Palestinian lands, the withdrawal of Israeli forces from the territories taken by the illegitimate use of force since 1967, the implementation of the Palestinian right to self-determination and the realization of the right of refugees to return home. All the refugees who 
were displaced during the creation of the State of Israel, their children and grandchildren must be permitted to return to their homeland of Palestine - this is the demand of international law. ${ }^{123}$ The implementation of this law depends on the political will of the major world powers, which is currently lacking, and also the political will of the members of the Organization of Islamic Conference (OIC). One of the objectives behind the establishment of the OIC was the liberation of Palestine from the yoke of Israeli occupation. This objective is yet to be realized and Palestine is yet to be liberated. The reason is we are not united and because of this a tiny nation, like Israel, can bully us. The member countries of the OIC must unite all their strengths, economically and politically, so as to achieve its prime objective, that is, to liberate Palestine.

$123 \quad$ Mr. Miguel d'Escoto Brockman, the former President of the UN General Assembly, Quoted in PalestineChronicle.com., available at www.radiofreepalestine.co.uk. 